\title{
Antimicrobial potency assay of common antibiotics collected from different drug stores in Dhaka Metropolis
}

\author{
Biswajit Modak, Md. Shahinur Rahman, Mohammad Shahid Gazi, Md. Aftab Uddin and Tasmina \\ Rahman* \\ Department of Microbiology, Stamford University Bangladesh, 51 Siddeswari Road, Dhaka 1217, \\ Bangladesh
}

Received 15 October 2013/Accepted 17 November 2013

\begin{abstract}
Antibiotic, known as the magic bullet, was developed to control the growth of pathogenic bacteria. Efficacy of an antibiotic depends on its target site on bacteria. The current public health issue is the emergence of resistant bacterial strains against these drugs. The present study was undertaken to perform the routine antibiotic susceptibility pattern of eight laboratory isolates (Escherichia coli, Bacillus spp., Staphylococcus spp., Vibrio spp., Salmonella spp., Pseudomonas spp., Klebsiella spp. and Listeria spp.) against eleven different categories of antibiotics (Ciprofloxacin, Cephradine, Metronidazole, Cefuroxime, Cefixime, Levofloxacin, Amoxicillin, Azithromycin, Doxycycline, Erythromycin and Flucloxacillin) available in local markets of Dhaka metropolis. Among these antibiotics, Azithromycin, Ciprofloxacin, Cefuroxime, Levofloxacin and Doxycycline showed the highest potency against these bacteria. On the contrary, Amoxicillin and Metronidazole showed almost no potency. Erythromycin, Cephradine and Flucloxacillin gave variable effectivity against the tested isolates. These findings reveal that measures for prevention and containment of antimicrobial resistance are necessary in Bangladesh.
\end{abstract}

Key words: Antimicrobial potency; Antibiotics; Pathogenic bacteria; Antimicrobial resistance

Antibiotics (literal meaning "against life") are chemical compounds produced by microorganisms that inhibit the normal regulation of some essential bacterial structure or function with limiting effects on eukaryotic host (1). The variety of antibiotic targets limits the use of them. The major groups of antibiotic classes inhibit four classical targets on bacterial structure and function: (i) cell wall biosynthesis, (ii) protein biosynthesis, (iii) DNA and RNA biosynthesis, and (iv) folate biosynthesis (1). Discovery of antibiotics has transfigured the era of medicine in many respects and numerous lives have been saved. Unfortunately, the use of these magic bullets has been accompanied by the rapid emergence of resistant strains (2).

Researches in the last few years documented that gene exchange is a widespread property of bacteria that results in microbial evolution. Antibiotic resistance can be either intrinsic (natural) or acquired $(3,4)$. Intrinsic resistance reflects the inherent or passive resistance of bacteria, which is a general consequence of bacterial adaptation technique. For an example, Pseudomonas aeruginosa has low membrane permeability which is the key to its innate resistance to many antibiotics (5).

${ }^{*}$ Corresponding Author: Mailing address. Tasmina Rahman, Department of Microbiology, Stamford University Bangladesh, 51 Siddeswari Road, Dhaka 1217, Bangladesh; E-mail: tasmina_mb@yahoo.com.
On the other hand, acquired or active resistance is resulted from the specific pressure of some antimicrobials which prepare the bacteria to counterattack against the specific class of antibiotics (6). Basically, this is resulted from the horizontal gene transfer from a resistant organism to a sensitive one.

As drug resistant organisms continued to appear, the Infectious Diseases Society of America (IDSA) has identified six pathogens as particular threats, as they cause the majority of nosocomial infections. In 2008, these pathogens are known as the ESKAPE bacteria Enterococcus faecium, Staphylococcus aureus, Klebsiella pneumoniae, Acinetobacter baumanii, Pseudomonas aeruginosa, and Enterobacter species $(7,8)$. Additionally, the emergence of community acquired methicillinresistant S. aureus (MRSA) (9) and extensively drugresistant (XDR) Mycobacterium tuberculosis (10, 11) exhibits that problematic resistance is not limited to the boundaries of the hospital.

It is vital that there should be no break in search of new antimicrobial agents (7). Advances in DNA sequencing and other genotyping technologies reveal that the DNA analysis of pathogens will very soon be widely accomplished in clinical and research backgrounds. Genotype-based antibiotic resistance profiling has been a faster technique in some cases, for example, rifampicin resistance in $M$. tuberculosis caused by nucleotide 
substitutions, and methicillin resistance in Staphylococcus aureus caused by a resistance cassette since several years (12). From the review of Kohanski et al. (13) it is revealed that the multi-layered effects of drug-target interactions contribute the killing of bacteria by antimicrobials. These interactions include inhibition of DNA replication, introduction of DNA breaks and replication fork arrest, the role of protein expression in quinolone-mediated cell death, role of the SOS response in cell death by $\beta$-lactams, aminoglycoside uptake and cell death, antibiotic networking and so on.

The above discussion focuses the evolution of antibiotic resistant strains of bacteria and the importance of newly developed antimicrobials. Taking those in mind, this study was conducted to reveal the situation of antibiotic resistance traits of eight laboratory bacterial strains against eleven different commercially consumed antibiotics.

\section{MATERIALS AND METHODS}

Sampling and sample processing. Samples of 11 categories of antibiotics including Amoxicillin Trihydrate (BP-2013 Volume 1\&2)- 535 mg (Moxilin capsule), Azithromycin (USP-32 Volume 2)- $4.12 \mathrm{mg}$ (Azix tablet), Doxycycline hydrochloride (BP-2013 Volume 1\&2)- $32.7 \mathrm{mg}$ (Doxycap capsule), Erythromycin (BP 2013 Volume 1\&2)- $2.14 \mathrm{mg}$ (Eromycine tablet), Flucloxacillin sodium (BP-2013 Volume 1\&2)- $6.72 \mathrm{mg}$ (Monoclox F), Ciprofloxacin $\mathrm{HCl}$ (USP-32 Volume-2)- $1.3 \mathrm{mg}$ (Amiflox tablet), Cephradine (BP-2013 Volume 1\&2)- $2.9 \mathrm{mg}$ (Belocef capsule), Cefixime (BP-2013 Volume 1\&2)- $1.10 \mathrm{mg}$ (Gen-3 capsule), Cefuroxime Axetil (BP-2013 Volume 1\&2)- $6.72 \mathrm{mg}$ (Lepath tablet), Levofloxacin Hemihydrates INN- $1.70 \mathrm{mg}$ (Levoxine tablet) and Metronidazole (BP-2013 Volume 1\&2)- $2.75 \mathrm{mg}$ (Mecozole tablet) were randomly collected during July 2013-August 2013 following standard protocol. For the detection of antibacterial activity against pathogens, all the samples (except amoxicillin) were homogenized with buffer peptone water, whereas amoxicillin was homogenized with distilled water.
Aqueous extraction of amoxicillin. $50 \mathrm{mg}$ of collected sample was added with sterile water to get a $100 \mathrm{ml}$ antibiotic solution after thoroughly shaking for 5 minutes in a volumetric flask. Then $1 \mathrm{ml}$ solution was taken to mix with $3 \mathrm{~m}$ distilled water. This $4 \mathrm{ml}$ solution was the desired extracted antibiotic sample (BP2013 Volume $1 \& 2$ )

Antimicrobial assay. The investigation of the antibacterial activity of the processed samples was performed by using agar well diffusion method $(14,15)$. In agar well diffusion method, solutions of different antibiotics were used directly on the Muller Hinton Agar separately. At first, laboratory strain of tested organisms, Pseudomonas spp, Listeria spp, Bacillus spp, Vibrio spp, Salmonella spp, Klebsiella spp, Staphylococcus aureus and Escherichia coli, were spread over the entire surface of MHA and wells were made by cork borer. Then, the antibiotic solution was added in the wells along with a positive control (Gentamycin disc: 10 $\mu \mathrm{g}$ ) and a negative control (normal saline). The presence of antimicrobial activity was determined by the production of clear zone around the wells and the diameters of these zones were then measured.

\section{RESULTS AND DISCUSSION}

Although antibiotics are used to treat various diseases, now-a-days they are becoming a major problem in health sector as the resistance against these drugs has been emerged within the bacterial population. Several reports from the scientific studies raised their concerns about the antibiotic resistant strain of bacteria and the limitation on the adequate knowledge improvisation during drug designing (7, 16-19). Among the various reasons, free supply and manufacture of antimicrobials, reduced antimicrobial therapy, insufficient access to effectual drugs and sometimes drugs of doubtful quality and overall poverty may play role in the development of antimicrobial resistance (20). In Bangladesh, few reports are available relating to systematic drug sensitivity pattern. A good, representative database on the current status of antibiotic resistance among common and important pathogens is essential for the proper treatment of infectious diseases in the country.

TABLE 1. Antibacterial activity of tested antibiotics against eight laboratory species

\begin{tabular}{|c|c|c|c|c|c|c|c|c|}
\hline \multirow{2}{*}{$\begin{array}{c}\text { Sample } \\
\text { (potency) }\end{array}$} & \multicolumn{8}{|c|}{ Zone of inhibition (mm) } \\
\hline & E. coli & $\begin{array}{c}\text { Bacillus } \\
\text { spp. }\end{array}$ & S. aureus & $\begin{array}{c}\text { Vibrio } \\
\text { spp. }\end{array}$ & $\begin{array}{l}\text { Salmonella } \\
\text { spp. }\end{array}$ & $\begin{array}{l}\text { Pseudomonas } \\
\text { spp. }\end{array}$ & $\begin{array}{c}\text { Klebsilla } \\
\text { spp. }\end{array}$ & $\begin{array}{c}\text { Listeria } \\
\text { spp. }\end{array}$ \\
\hline $\begin{array}{l}\text { Flucloxacillin } \\
(6.72 \mathrm{mg})\end{array}$ & $\begin{array}{c}25 \mathrm{~mm} \\
(\mathrm{~S})\end{array}$ & $\begin{array}{c}20 \mathrm{~mm} \\
(\mathrm{~S})\end{array}$ & $\begin{array}{c}29 \mathrm{~mm} \\
(\mathrm{~S})\end{array}$ & $\begin{array}{c}21 \mathrm{~mm} \\
(\mathrm{~S})\end{array}$ & $\begin{array}{l}20 \mathrm{~mm} \\
(\mathrm{~S})\end{array}$ & $\begin{array}{c}26 \mathrm{~mm} \\
(\mathrm{~S})\end{array}$ & $\begin{array}{c}0 \mathrm{~mm} \\
(\mathrm{R})\end{array}$ & $\begin{array}{c}16 \mathrm{~mm} \\
(\mathrm{R})\end{array}$ \\
\hline $\begin{array}{l}\text { Azithromycin } \\
\text { (4.12 mg) }\end{array}$ & $\begin{array}{l}29 \mathrm{~mm} \\
(\mathrm{~S})\end{array}$ & $\begin{array}{c}35 \mathrm{~mm} \\
(\mathrm{~S})\end{array}$ & $\begin{array}{l}30 \mathrm{~mm} \\
(\mathrm{~S})\end{array}$ & $\begin{array}{l}24 \mathrm{~mm} \\
(\mathrm{~S})\end{array}$ & $\begin{array}{l}22 \mathrm{~mm} \\
(\mathrm{~S})\end{array}$ & $\begin{array}{c}32 \mathrm{~mm} \\
(\mathrm{~S})\end{array}$ & $\begin{array}{l}21 \mathrm{~mm} \\
(\mathrm{~S})\end{array}$ & $\begin{array}{l}21 \mathrm{~mm} \\
(\mathrm{~S})\end{array}$ \\
\hline $\begin{array}{c}\text { Doxycycline } \\
(32.70 \mathrm{mg})\end{array}$ & $\begin{array}{l}30 \mathrm{~mm} \\
(\mathrm{~S})\end{array}$ & $\begin{array}{c}37 \mathrm{~mm} \\
(\mathrm{~S})\end{array}$ & $\begin{array}{c}33 \mathrm{~mm} \\
(\mathrm{~S})\end{array}$ & $\begin{array}{l}40 \mathrm{~mm} \\
(\mathrm{~S})\end{array}$ & $\begin{array}{l}38 \mathrm{~mm} \\
\text { (S) }\end{array}$ & $\begin{array}{l}40 \mathrm{~mm} \\
\text { (S) }\end{array}$ & $\begin{array}{l}24 \mathrm{~mm} \\
(\mathrm{~S})\end{array}$ & $\begin{array}{c}29 \mathrm{~mm} \\
(\mathrm{~S})\end{array}$ \\
\hline $\begin{array}{l}\text { Erythromycin } \\
(2.14 \mathrm{mg})\end{array}$ & $\begin{array}{c}35 \mathrm{~mm} \\
\text { (S) }\end{array}$ & $\begin{array}{l}27 \mathrm{~mm} \\
\text { (S) }\end{array}$ & $\begin{array}{l}35 \mathrm{~mm} \\
\text { (S) }\end{array}$ & $\begin{array}{c}28 \mathrm{~mm} \\
(\mathrm{~S})\end{array}$ & $\begin{array}{l}27 \mathrm{~mm} \\
\text { (S) }\end{array}$ & $\begin{array}{l}34 \mathrm{~mm} \\
\text { (S) }\end{array}$ & $\begin{array}{l}17 \mathrm{~mm} \\
\text { (I) }\end{array}$ & $\begin{array}{l}15 \mathrm{~mm} \\
(\mathrm{R})\end{array}$ \\
\hline $\begin{array}{l}\text { Amoxicillin } \\
(50 \mathrm{mg})\end{array}$ & $\begin{array}{l}0 \mathrm{~mm} \\
(\mathrm{R})\end{array}$ & $\begin{array}{l}0 \mathrm{~mm} \\
(\mathrm{R})\end{array}$ & $\begin{array}{l}18 \mathrm{~mm} \\
\text { (R) }\end{array}$ & $\begin{array}{l}19 \mathrm{~mm} \\
\text { (I) }\end{array}$ & $\begin{array}{l}0 \mathrm{~mm} \\
(\mathrm{R})\end{array}$ & $\begin{array}{l}0 \mathrm{~mm} \\
(\mathrm{R})\end{array}$ & $\begin{array}{l}0 \mathrm{~mm} \\
(\mathrm{R})\end{array}$ & $\begin{array}{l}0 \mathrm{~mm} \\
(\mathrm{R})\end{array}$ \\
\hline $\begin{array}{l}\text { Ciprofloxacin } \\
\quad(1.30 \mathrm{mg})\end{array}$ & $\begin{array}{l}35 \mathrm{~mm} \\
(\mathrm{~S})\end{array}$ & $\begin{array}{l}40 \mathrm{~mm} \\
\text { (S) }\end{array}$ & $\begin{array}{l}35 \mathrm{~mm} \\
\text { (S) }\end{array}$ & $\begin{array}{l}40 \mathrm{~mm} \\
\text { (S) }\end{array}$ & $\begin{array}{l}39 \mathrm{~mm} \\
(\mathrm{~S})\end{array}$ & $\begin{array}{l}36 \mathrm{~mm} \\
(\mathrm{~S})\end{array}$ & $\begin{array}{l}19 \mathrm{~mm} \\
\text { (I) }\end{array}$ & $\begin{array}{l}27 \mathrm{~mm} \\
(\mathrm{~S})\end{array}$ \\
\hline $\begin{array}{c}\text { Cephradine } \\
(2.90 \mathrm{mg})\end{array}$ & $\begin{array}{l}37 \mathrm{~mm} \\
(\mathrm{~S})\end{array}$ & $\begin{array}{l}22 \mathrm{~mm} \\
\text { (I) }\end{array}$ & $\begin{array}{l}36 \mathrm{~mm} \\
(\mathrm{~S})\end{array}$ & $\begin{array}{c}27 \mathrm{~mm} \\
\text { (I) }\end{array}$ & $\begin{array}{l}20 \mathrm{~mm} \\
\text { (I) }\end{array}$ & $\begin{array}{l}35 \mathrm{~mm} \\
\text { (S) }\end{array}$ & $\begin{array}{c}0 \mathrm{~mm} \\
(\mathrm{R})\end{array}$ & $\begin{array}{c}23 \mathrm{~mm} \\
\text { (I) }\end{array}$ \\
\hline $\begin{array}{l}\text { Metronidazole } \\
\quad(2.75 \mathrm{mg})\end{array}$ & $\begin{array}{l}0 \mathrm{~mm} \\
(\mathrm{R})\end{array}$ & $\begin{array}{l}0 \mathrm{~mm} \\
(\mathrm{R})\end{array}$ & $\begin{array}{l}0 \mathrm{~mm} \\
(\mathrm{R})\end{array}$ & $\begin{array}{l}0 \mathrm{~mm} \\
(\mathrm{R})\end{array}$ & $\begin{array}{l}0 \mathrm{~mm} \\
(\mathrm{R})\end{array}$ & $\begin{array}{l}0 \mathrm{~mm} \\
(\mathrm{R})\end{array}$ & $\begin{array}{c}0 \mathrm{~mm} \\
(\mathrm{R})\end{array}$ & $\begin{array}{l}0 \mathrm{~mm} \\
(\mathrm{R})\end{array}$ \\
\hline $\begin{array}{l}\text { Cefuroxime } \\
(6.72 \mathrm{mg})\end{array}$ & $\begin{array}{c}23 \mathrm{~mm} \\
\text { (S) }\end{array}$ & $\begin{array}{l}29 \mathrm{~mm} \\
\text { (S) }\end{array}$ & $\begin{array}{c}26 \mathrm{~mm} \\
\text { (S) }\end{array}$ & $\begin{array}{l}18 \mathrm{~mm} \\
(\mathrm{~S})\end{array}$ & $\begin{array}{l}32 \mathrm{~mm} \\
\text { (S) }\end{array}$ & $\begin{array}{l}28 \mathrm{~mm} \\
\text { (S) }\end{array}$ & $\begin{array}{l}28 \mathrm{~mm} \\
(\mathrm{~S})\end{array}$ & $\begin{array}{l}19 \mathrm{~mm} \\
\text { (S) }\end{array}$ \\
\hline $\begin{array}{l}\text { Cefixime } \\
(1.10 \mathrm{mg})\end{array}$ & $\begin{array}{l}0 \mathrm{~mm} \\
(\mathrm{R})\end{array}$ & $\begin{array}{l}0 \mathrm{~mm} \\
(\mathrm{R})\end{array}$ & $\begin{array}{l}0 \mathrm{~mm} \\
(\mathrm{R})\end{array}$ & $\begin{array}{l}0 \mathrm{~mm} \\
(\mathrm{R})\end{array}$ & $\begin{array}{l}35 \mathrm{~mm} \\
\text { (S) }\end{array}$ & $\begin{array}{l}0 \mathrm{~mm} \\
(\mathrm{R})\end{array}$ & $\begin{array}{l}0 \mathrm{~mm} \\
(\mathrm{R})\end{array}$ & $\begin{array}{l}10 \mathrm{~mm} \\
(\mathrm{R})\end{array}$ \\
\hline $\begin{array}{l}\text { Levofloxacin } \\
(1.70 \mathrm{mg})\end{array}$ & $\begin{array}{l}40 \mathrm{~mm} \\
\text { (S) }\end{array}$ & $\begin{array}{l}30 \mathrm{~mm} \\
\text { (S) }\end{array}$ & $\begin{array}{c}36 \mathrm{~mm} \\
(\mathrm{~S})\end{array}$ & $\begin{array}{c}36 \mathrm{~mm} \\
(\mathrm{~S})\end{array}$ & $\begin{array}{c}39 \mathrm{~mm} \\
\text { (S) }\end{array}$ & $\begin{array}{c}36 \mathrm{~mm} \\
\text { (S) }\end{array}$ & $\begin{array}{l}24 \mathrm{~mm} \\
\text { (S) }\end{array}$ & $\begin{array}{c}27 \mathrm{~mm} \\
(\mathrm{~S})\end{array}$ \\
\hline
\end{tabular}

$\mathrm{R}=$ Resistant $; \mathrm{S}=$ Sensitive; $\mathrm{I}=$ Intermediate 
Current study was designed to assess some broad spectrum antibiotics available in drug stores of Dhaka city. The efficacy of the antibiotics was determined against the laboratory strains of some common etiological agents of different diseases. it was evident that Azithromycin, Doxycyclin, Ciprofloxacin, Cefuroxime and Levofloxacin showed affectivity against all tested bacteria.

A study suggested that Pseudomonas aeruginosa responsible for wound, urine, ear, throat and other infections was more than $50 \%$ resistant to commonlyused antibiotics in Bangladesh, including Ciprofloxacin, Gentamicin, Ceftriaxone, Cefixime and Azithromycin (21). However, in this study, the tested Pseudomonas strain was found to be sensitive against all these antibiotics except Cefixime. Another study also reported Escherichia coli as a resistant isolate in $40 \%$ of cases to commonly used antibiotics Ceftriaxone, Levofloxacin, Ciprofloxacin, Amoxicillin and Ampicillin (22), while the current study revealed the sensitive nature of this bacteria against a wide range of antibiotics including Flucloxacillin, Azithromycin, Doxycycline, Ciprofloxacin, Cephradine, Cefuroxime and Levofloxacin. Several other studies reported the highly resistant pattern of pathogenic bacteria like Vibrio spp., Salmonella spp. and Staphylococcus aureus (23-25). These results contradict the findings of the current study where all these bacteria gave sensitivity against most of the tested antibiotics.

Drug-resistant bacterial infections are becoming more prevalent and are a major health issue in current days (26-28). This rise in resistance has created a problematic situation which has been intensified by the small number of new antibiotics developed in recent years. It will be important to improvise our growing knowledge of antibiotic mechanisms into new clinical treatments and approaches, so that we can effectively fight the growing threat from resistant pathogens (29).

A potential reason of bacteria being resistant to antibiotics is intensive drug abuse. In Bangladesh, there is no national antimicrobial policy and few institutes have antimicrobial guidelines which are also not in practice (30). There is no uniformity among the prescribers in commonly prevalent infections although national guidelines are prepared for certain important prevalent infections, for example malaria, kala-azar and tuberculosis. Completion of the course of the prescribed antibiotic is not supervised and is likely to be poor in compliance for various reasons. All these factors facilitate antimicrobial resistance. Moreover, polypharmacy is very common among the rural medical practitioners with antibiotics and vitamins prescribed widely (31). The prescription procedure of antibiotics in Bangladesh is less than ideal as prior identification of the pathogens and its sensitivity to the drug is rarely determined before the drug is prescribed (32).

Hence, it is clear that antibiotic resistance will continue to emerge and disseminate, and demand research attempts to identify and develop new therapeutic options. The situation can be controllable only with considerable efforts from the research community, pharmaceutical industry, and regulatory bodies, to improve the productivity of new antibiotics and treatment options for the resistant bacteria and to control the antibiotic drug abuse.

So, overall we found the range of susceptibility of different microorganisms against mostly used antibiotics. Most of the isolates showed different degrees of resistance which may lead to serious public health risk. In our study, we pictured a complete profile of susceptibility of various pathogens against several antibiotics showing a high range of resistance. Thus it can be concluded that routine examination of the antibiotic sensitivity pattern of etiological agents is very much required to reduce the burden of health care costs by choosing the appropriate antibiotic, as well as different assay method needs to be established by different local and international bodies for determining the potency of the active ingredients of the antibiotic that is mentioned on the drug.

\section{REFERENCES}

1. Walsh, C. 2003. Antibiotic, action, origins, resistance. ASM press, Washington, DC.

2. Liu, B., and M. Pop. 2009. ARDB-Antibiotic resistance genes database. Nucleic Acids Res. 37: D443-D447.

3. Hacker, J., and J. B. Kaper. 2000. Pathogenicity islands and the evolution of microbes. Annu. Rev. Microbiol. 54: 641-679.

4. Norman, A., L. H. Hansen, and S. J. Sorensen. 2009. Conjugative plasmids vessels of the communal gene pool. Philos. Trans. R. Soc. Lond. B. Biol. Sci. 364: 2275-2289.

5. Yoneyama H., and R. Katsumata. 2006. Antibiotic resistance in bacteria and its future for novel antibiotic development. Biosci. Biotechnol. Biochem. 70: 1060-107.

6. Wright G. D. 2005. Bacterial resistance to antibiotics: enzymatic degradation and modification. Adv. Drug Del. Rev. 57: 1451-1470.

7. Boucher, H. W., et al. 2004. No Drugs: No ESKAPE! An update from the infectious diseases society of America. Clin. Infect. Dis. 48: 1-12.

8. Rice, L. B. 2008. Federal funding for the study of antimicrobial resistance in nosocomial pathogens: no ESKAPE. J. Infect. Dis. 197: 1079-81.

9. Stryjewski, M. E., and H. F. Chambers. 2008. Skin and soft-tissue infections caused by community acquired methicillin resistant Staphylococcus aureus. Clin. Infect. Dis. 46: S368-77.

10. Jassal, M., and W. R. Bishai. 2009. Extensively drug-resistant tuberculosis Lancet Infect. Dis. 9: 19-30.

11. Noor R., et al. 2013. Frequency of extensively drug resistant tuberculosis (XDR-TB) among re-treatment cases in NIDCH, Dhaka, Bangladesh J. Infec. Chemother. 19 (2): 243-248.

12. idelot, X., et al. 2012. Transforming clinical microbiology with bacterial genome sequencing. Nature Rev. Genet. 13: 601-612.

13. Kohanski M. A., D. J. Dwyer, and J. J. Collins. 2010. How antibiotics kil bacteria: from targets to networks. Nat. Rev. Microbiol. 8 (6): 423-435.

14. Jagessar, R. C., A. Mars, and G. Gones. 2008. Selective antimicrobial properties of leaf extract against various micro-organisms using Disc diffusion and Agar well diffusion method. J. Nat. Sci. 6 (2): 24-38.

15. Ahmed, T., et al. 2013. Identification of drug-resistant bacteria among export quality shrimp samples in Bangladesh. Asian J. Microbiol. Biotech. Env. Sc. 15 (4): 655-660.

16. Bradley, J.S., et al. 2007. Anti-infective research and development: problems, challenges, and solutions. Lancet Infect. Dis. 7: 68-78.

17. Cars, O., et al. 2008. Meeting the challenge of antibiotic resistance. BMJ 337: a1438. 
18. Nathan, C. 2004. Antibiotics at the crossroads. Nature 431: 89-902.

19. Norrby, S. R., C. E. Nord, and R. Finch. 2005. Lack of development of new antimicrobial drugs: a potential serious threat to public health. Lancet Infect. Dis. 5: 115-119.

20. World Health Organization. 2000. Overcoming antimicrobial resistance. Geneva, Switzerland.

21. Rashid, A., et al. 2007. Infections by Pseudomonas aeruginosa and antibiotic resistance pattern of the isolates from Dhaka Medical College Hospital. Bangladesh J. Med. Microbiol. 1 (2): 48-51.

22. Lina, T. T., S. R. Rahman, and D. J. Gomes. 2007. Multiple-antibiotic resistance mediated by plasmid and integrons in uropathogenic Escherichia coli and Klebsiella pneumoniae. Bangladesh J. Microbiol. 24 (1): 19-23.

23. World Health Organization. 2010. Regional strategy for prevention and contaminant of antimicrobial resistance. WHO regional office for South East Asia, New Delhi.

24. Rahman M. T., N. Kobayashi, M. M. Alam, and M. Iahino. 2005. Genetic analysis of mecA homologous in Staphylococcus sciuri strains derived from mastitis in dairy cattle. Microbiol. Drug. Resist. 11: 205-214.

25. Rasul, C. H., M. A. Hassan, and M. Habibullah. 2007. Neonatal sepsis and use of antibiotics in a tertiary care hospital. Pakistan J. Med. Sci. 23 (1): $78-81$.
26. Yeh, P. J., M. J. Hegreness, A. P. Aiden, and R. Kishony. 2009. Drug interactions and the evolution of antibiotic resistance. Nat. Rev. Microbiol. 7 460-6.

27. Bollenbach, T., S. Quan, R. Chait, and R. Kishony. 2009. Nonoptimal microbial response to antibiotics underlies suppressive drug interactions. Cell 139: 707-18.

28. Bozdogan, B., and P. C. Appelbaum. 2004. Oxazolidinones: activity, mode of action, and mechanism of resistance. Int. J. Antimicrob. Agents 23: 113119.

29. Kohanski M. A., D. J. Dwyer, and J. J. Collins. 2010. How antibiotics kill bacteria: from targets to networks. Nat. Rev. Microbiol. 8 (6): 423-435.

30. Jassal, M., and W. R. Bishai. 2009. Extensively drug-resistant tuberculosis. Lancet Infect. Dis. 9: 19-30.

31. Chowdhury, F. R., M. M. Rahman, M. F. Huq, and S. Begum. 2006. Rationality of drug uses: its Bangladeshi perspective. Mymensingh Med. J. 15 (2): 215-9.

32. Ronsmans, C., T. Islam, and M. L. Bennish. 1996. Medical practitioners' knowledge of dysentery treatment in Bangladesh. British Med. J. 313: 205206. 